Article

\title{
Reduction of Fuel Consumption and Pollution Emissions in Inland Water Transport by Application of Hybrid Powertrain
}

\author{
Andrzej Lebkowski \\ Department of Ship Automation, Gdynia Maritime University, Poland Morska St. 83, 81-225 Gdynia, Poland; \\ a.lebkowski@we.am.gdynia.pl
}

Received: 6 July 2018; Accepted: 27 July 2018; Published: 30 July 2018

check for updates

\begin{abstract}
The article presents the analysis of application of hybrid propulsion systems combining conventional diesel with electric drive for units used in inland transport. The answer is given to the question: to what extent will the use of different configurations of hybrid systems, affect the reduction of fuel consumption and reduce poisonous gases to the atmosphere? Various configurations of propulsion systems have been proposed: liquefied natural gas (LNG)-Diesel, LNG-Diesel-Electric, LNG-Diesel-Battery-Electric, against the background of the current state of inland waterway transport in central Europe. The announced plans to expand the network of existing international water routes in this region of Europe (E30, E40, E70), prompts a reflection on the simultaneous possibility of building modern low-emission and energy-efficient inland transport vessels. As an example of a modern drive system design, LNG-Diesel-Battery-Electric was proposed for which simulations were carried out using Modelica software. The conducted research has shown the possibility of reducing energy consumption by approximately $13 \%$ in relation to the classical drive system with a diesel engine, and reduction of $\mathrm{CO}_{2}$ emissions by approx. $29 \%$ with respect to the conventional diesel drive.
\end{abstract}

Keywords: electric barge; hybrid systems; air pollution; electric powertrain; inland ship; energy saving

\section{Introduction}

Development of transport systems is an indispensable element of the development of the economy of the states. More than 90 percent of global trade goods are carried by water transport [1,2]. One of the types of systems used for the transport of people and freight is inland transport. It is one of the oldest transport systems in the world, and due to its use of natural geographical conditions, such as the location of rivers, it contributed and influenced the development of many significant civilizations.

The largest cities in the world were established by local rivers. They are natural roads, which have been used for transportation since the beginning of civilization, at first using primitive rafts which later evolved into barges. Most of the currently used transport barges use diesel as fuel, which results in emission of pollution, contributing to the development of human diseases and the greenhouse effect. These poisonous substances generated from burnt fuel spread to the area where barges are used. This effect could be reduced by using hybrid and electric powertrains.

The use of hybrid powertrain on barges and small ships is very important not only because of the possibility of limiting emission of pollutant gases to the atmosphere [3,4], but also from the aspect of energy savings and reduction of operating costs [5,6]. The reduction of costs of an inland vessel is related to the operation of internal combustion engines in terms of their optimal parameters, i.e., those for which the efficiency of internal combustion engines is the greatest. These engines work 
most efficiently under a load of $80-85 \%$ of nominal power, and it is beneficial to create a situation where such a load is required to generate an appropriate amount of energy for the electric part of the drive system. In world literature, various analyzes [7], and methods [8-10] can be found, concerning the reduction of pollution emitted to the atmosphere by the internal combustion engines.

Many major shipping routes in the world run along the main rivers of Western Europe. The possibility of reducing the emission of toxic gases into the atmosphere generated by diesel engines, as well as the reduction of transport costs, are inspirations for programs intended to stimulate the development of this type of transport.

One of the countries in which the rapid growth of inland waterway transport can take place in the near future is Poland. This is a great opportunity to apply modern hybrid technology to drive a barge.

The Polish government is planning to transfer around $30 \%$ of road freight transport on distances longer than $300 \mathrm{~km}$ to water or rail transport by 2030, and 50\% by 2050 [3]. In order to fulfill this task, in January 2017 the Polish President signed the act ratifying the European Agreement on Main Inland Waterways of International Importance (AGN) Convention, which was previously accepted by the Polish Government and the Parliament. By ratifying the AGN Convention, Poland committed itself to upgrading the main waterways to at least Class IV of navigability. Figure 1 shows the operating parameters describing the classes of inland waterways [3].

In the Western Europe, where most of the waterways are of Classes V and VI, the operating stock is dominated mostly by self-propelled barges (in Germany, France, Belgium, and the Netherlands) [4].

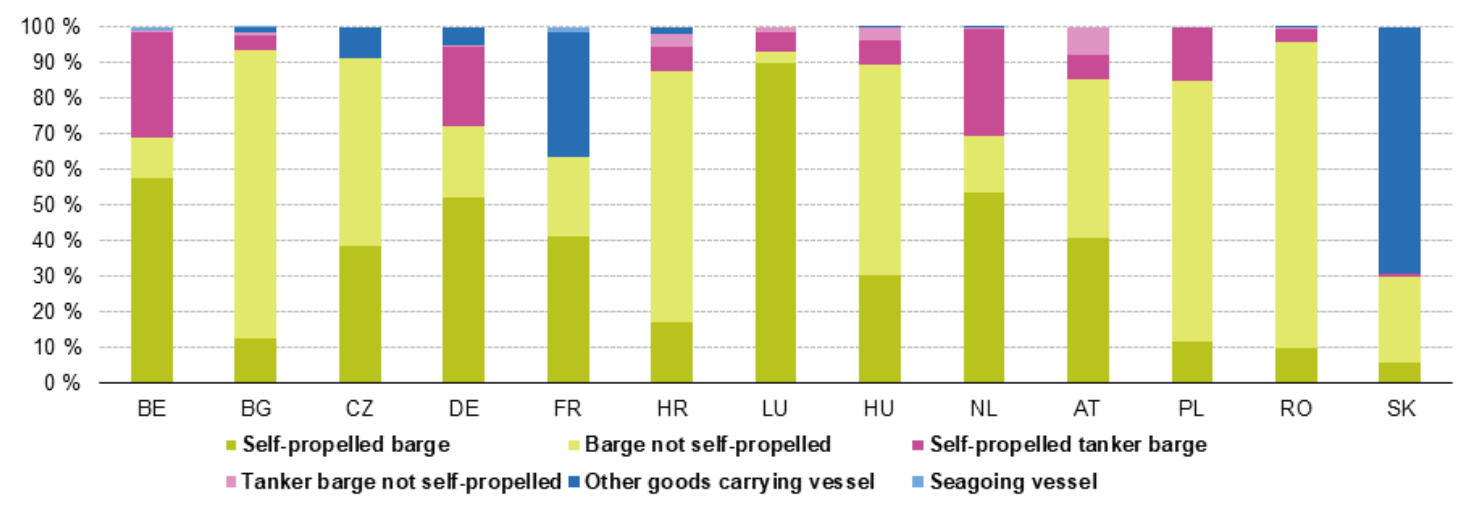

Figure 1. Share by type of vessel in total transport in 2016-\% in tons [4]. BE: Belgium; BG: Bulgaria; CZ: Czechia; DE: Germany; FR: France; HR: Croatia; LU: Luxembourg; HU: Hungary; NL: Netherlands; AT: Austria; PL: Poland; RO: Romania; and SK: Slovakia.

Three major sections of international waterways run through Poland: E30-linking the Baltic Sea from the port of Swinoujscie through the Oder, the future Danube-Odra-Elbe Canal through the Danube to Bratislava, E40-connecting the Baltic Sea from Gdansk through the Vistula River to Warsaw, Narew and Bug to Brest and further through the Dnepr to the Black Sea In Odessa, E70—connecting the Odra River from the estuary of the Odra-Hawel Canal to the estuary of the Warta River in Kostrzyn, via Bydgoszcz, the Lower Vistula and Szkarpawa or the Vistula Lagoon with the Vistula Lagoon, creating a European waterway route between Rotterdam and Klaipeda [3,11,12].

The development of inland water transport in Poland dynamics was variable. The first signs of the existence of organized inland waterway transport in Poland can be found in the privilege granted by Bolesław Śmiały (Boleslaw the Bold) in 1065 to a monastery in Mogilno near Inowrocław, which provided freedom of navigation to monasteries on the entirety of Vistula River to the Baltic Sea. Since the 13th century, cities such as Bochnia, Połaniec, Sandomierz, Chełmno, Torun and others have been granted the privilege of shipping. Transport of goods, mainly salt and herrings, was also taking place on the Odra River. In the 13th century Prince Henryk Brodaty endorsed the duty-free transport of herring from Pomerania to the monastery in Lubiaz. The same monastery received from 
the prince Wladyslaw Odonica the right of free passage from Glogow to the estuary of Obra. During XVI and XVII centuries in the Polish state inhabited by 7.5 million, the inland waterway transport was employing about 25 thousand people. Further development of inland waterway transport in the nineteenth century contributed to the construction of canal connections and infrastructure surviving to date [12]. The beginning of the era of transport of the largest number of goods in Poland falls in the XX century (Figure 2), in the mid-70s, when inland waterways carried about 14 million tons of cargo a year. In 1980, the amount of freight carried was already 22 million tons, falling to about 10 million tons in 1990 [11]. The decline in freight traffic after 1989 has contributed to a decrease in concern of infrastructure and the general state of waterways in Poland.

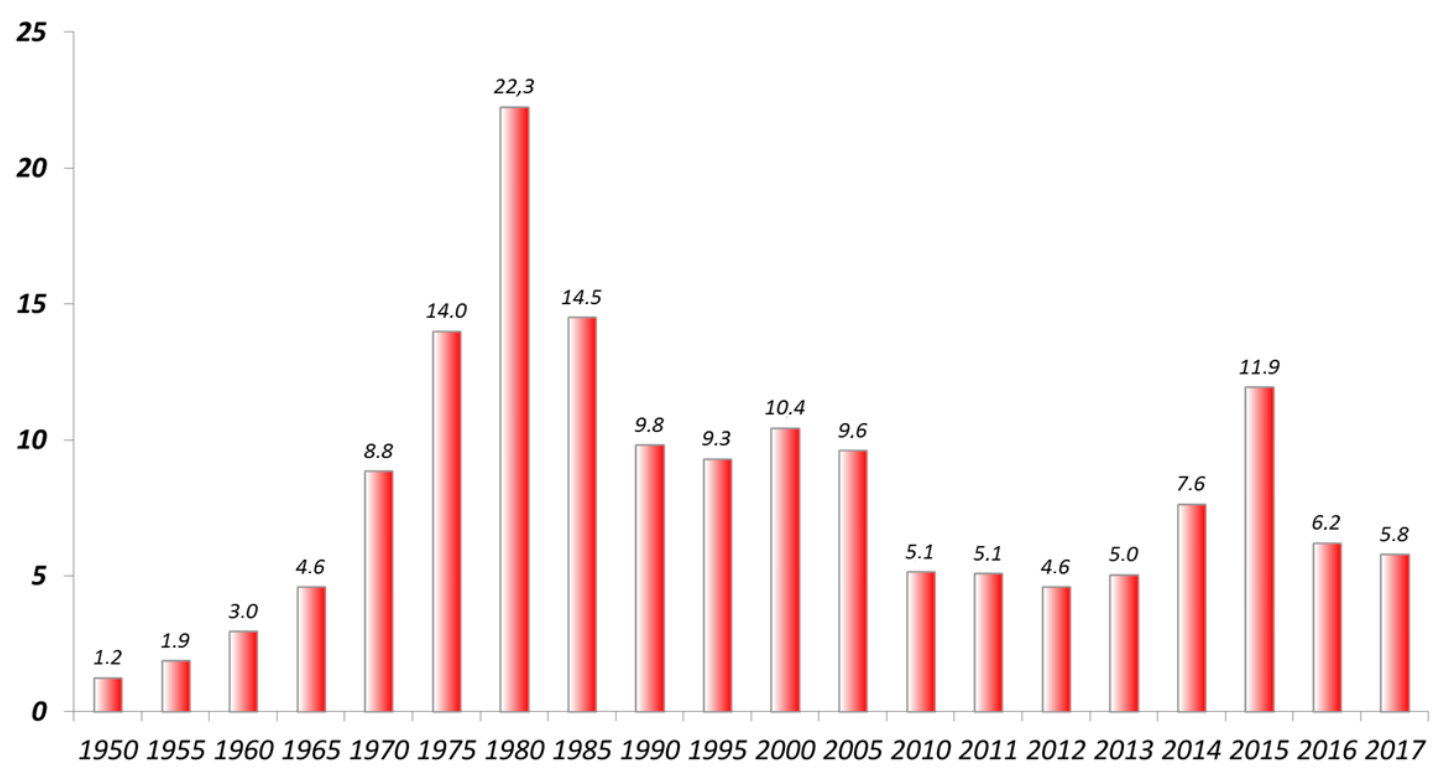

Figure 2. Transportation of goods in Poland using inland waterway transport in the years 1950-2017 [3].

At present there are about $3655 \mathrm{~km}$ of waterways, of which $2417 \mathrm{~km}$ are regulated navigable rivers, $644 \mathrm{~km}$ channeled sections of rivers, $336 \mathrm{~km}$ of canals, and $259 \mathrm{~km}$ of navigable waters. Approximately $92 \%$ of accessible waterways $(3365 \mathrm{~km}$ ) are used for navigation, but the requirements for Classes IV and V waterways in 2015 were met by only $5.9 \%$ of waterways $(214 \mathrm{~km})$. The remaining $94.1 \%$ of waterways $(3441 \mathrm{~km})$ are in Classes I, II and III [11]. The situation with the stock of inland transport is similarly unsatisfactory. According to the Central Statistical Office in Poland, the majority of operated units, i.e., $73.0 \%$ of pushers, $48.7 \%$ of barges and $100 \%$ of self-propelled barges, were built in the 1949 to 1979 period. Most of the equipment used in Poland are pushed units $(85 \%)$, which carried about $45 \%$ of total goods transported by inland waterways. Such a state of affairs is resulting mainly from the poor condition of waterways in Poland.

The advantages of inland waterway transport are: low transport costs, high environmental performance due to low carbon dioxide emissions, and a high level of safety. The greatest benefits of inland waterway transport stem from the large cargo capacity of its vessels, and relatively low power needed to propel them. With respect to rail or road transport, the disadvantage of inland transport is the length of time the goods are transported. For this reason, inland transport can mainly be used to transport long-term stable goods such as coal, aggregates, ores, building materials, agricultural products, crude oil products, steel and ferrous metals, chemical products, vehicles, machinery, semi-finished products, bulk cargo and containers.

Considering the plans for the modernization of international waterways which runs through Polish territory, the author proposes the use of a hybrid propulsion system, consisting of dual fuel (liquefied natural gas (LNG)-Diesel) generator sets, indirect stage of energy transfer in the form of battery packs, and electric propulsion motors. Several models have been developed to obtain the 
full range of results associated with the different configurations of the barge propulsion system. The models are: Diesel-Propeller (DP); Diesel + LNG-Propeller (DLP); Diesel-Electric-Propeller (DEP); Diesel + LNG-Electric-Propeller (DLEP), Diesel-Battery-Electric-Propeller (DBEP), and Diesel + LNG-Battery-Electric-Propeller (DLBEP). The main elements that were analyzed are the power consumption of the hybrid propulsion system, and associated air pollution, compared to conventional internal combustion engine powertrain operating in identical conditions. The conducted simulation research and the results, which constitute the novelty of the paper, confirm that the application of the hybrid powertrain in inland transport vessels can positively impact the reduction of energy consumption and emission of pollution into the atmosphere.

\section{Structure of the Powertrain}

Reduction of air pollution by internal combustion engines is one of the main ideological trends of the European Union. This goal is achievable by using fuels with appropriate parameters, i.e., those that do not contain sulphur compounds.

Inland vessels used for the transport of people and goods are currently being driven by internal combustion engines working in the Diesel (air is compressed so much that it heats up and can ignite the fuel) or Otto (the fuel-air mixture must be ignited with a spark) cycles. In addition, these engines can be powered by various fuels such as: Ultra Low Sulphur Diesel (ULSD) fuel; biofuels (methanol and biomethanol (EN 228), dimethyl ether-DME (EN 590), biodiesel or FAME (EN 14214, ASTM D6751, EN 590), hydrogen derived renewable diesel (ASTM D 975), algae biofuel); gaseous fuels (liquefied propane gas_LPG, biomethane-Bio LNG); FT fiesel; pyrolysis oil (ASTM D 7544); Hydrogen [5]. Quality standards for fossil fuels used in inland waterway transport are set out in Directive EU 2015/652. The specific properties and availability of individual fuels makes it possible to use them in hybrid powertrain systems.

Figure 3 shows the configuration of the propulsion system for a barge with diesel-LNG dual fuel engines, it consists of two dual fuel diesel engines driving a single propeller via a common reduction gearbox.

This section may be divided by subheadings. It should provide a concise and precise description of the experimental results, their interpretation as well as the experimental conclusions that can be drawn.

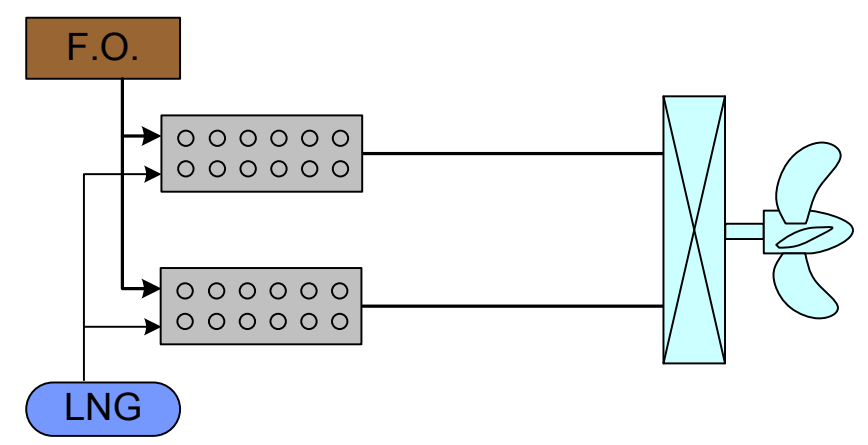

Figure 3. Structure of a dual fuel liquefied natural gas (LNG)-Diesel powertrain.

Another configuration is the one consisting of Diesel-LNG dual fuel generators and electric motors (Figure 4). It is a system with three dual fuel diesel generators, an AC distribution network, and two power converters supplying two electric motors, which drive a single propeller via a common reduction gearbox. In periods of low power demand, only one diesel generator needs to operate, and the difference in nominal power of the generators allows selecting which generator(s) to run, so they would operate in the most efficient way possible. The selection of running generator sets is performed by the Power Management System (PMS) [13]. 


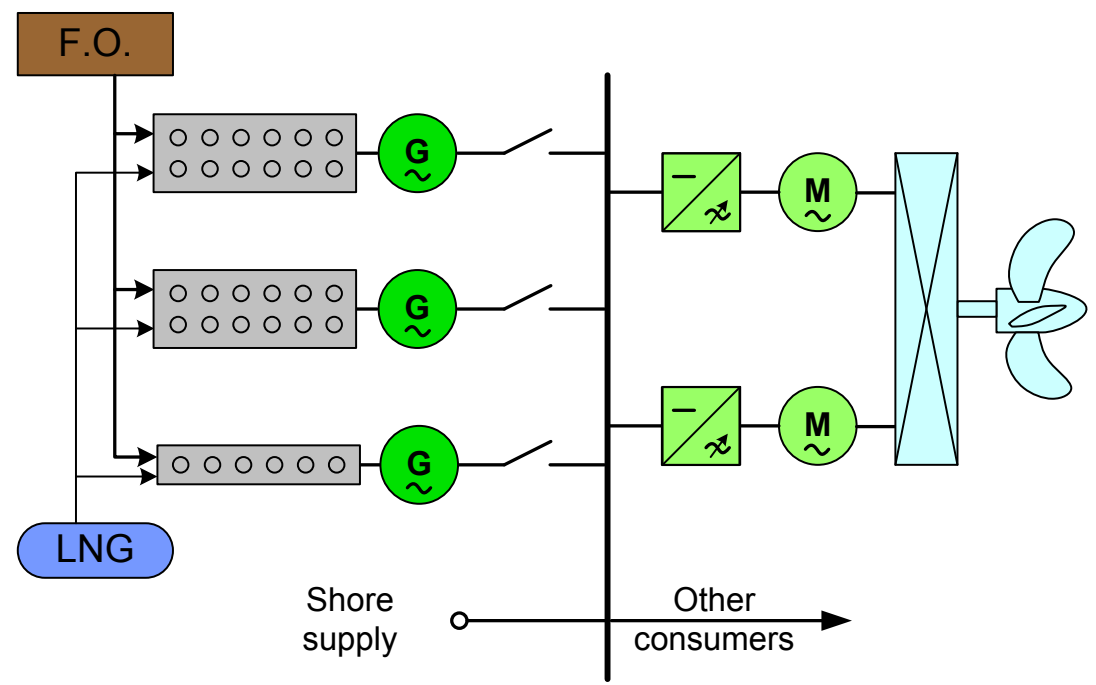

Figure 4. Structure of a dual fuel LNG-Diesel-Electric powertrain.

The most elaborate configuration built in the course of the study is a hybrid propulsion system consisting of dual fuel generator sets (Diesel + LNG) that deliver electricity through a battery pack for electric motors. In this system three dual fuel diesel generators are supplying their dedicated AC/DC power converters, which power a DC distribution network with battery energy storage. Two DC/AC inverters consume power from the DC network and drive two electric motors which, in turn, drive a single propeller via a common reduction gearbox. The structure of this system is shown in Figure 5.

The use of LNG as fuel for Diesel cycle engines has a positive impact on the environment by reducing emissions of $\mathrm{NO}_{\mathrm{x}}, \mathrm{SO}_{\mathrm{x}}, \mathrm{PM} 10, \mathrm{CO}_{2}, \mathrm{CH}_{4}, \mathrm{~N}_{2} \mathrm{O}$ [5]. In addition, the use of LNG compared to diesel reduces the unit's operating costs. The use of the Diesel-Electric hybrid system can reduce the operating cost of the barge by about $20 \%$ [6]. In addition, supplying the generators with LNG fuel reduces operating costs.

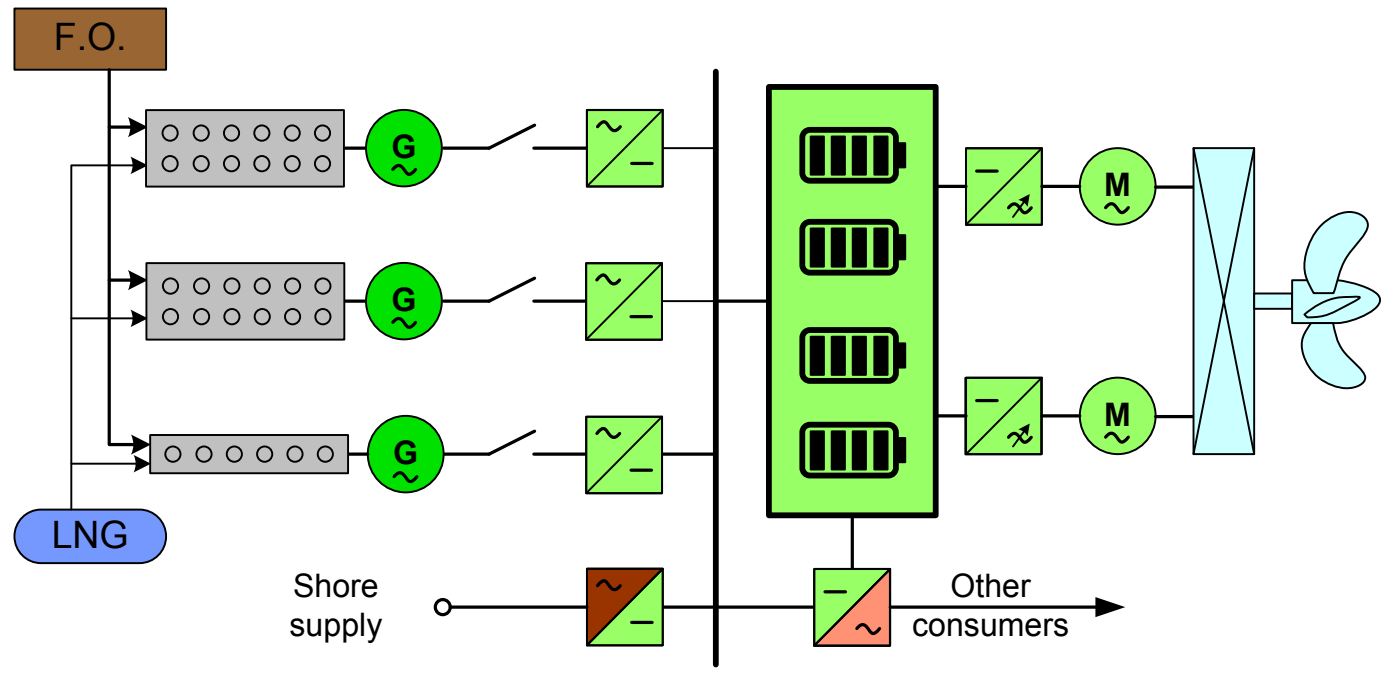

Figure 5. Structure of a dual fuel LNG-Diesel-Battery-Electric powertrain.

The use of electric motors, as the last power transmission link, optimizes the efficiency of the entire propulsion system, due to the high efficiency of electric drives. In addition, electric drives are characterized by: a neutral impact on the environment (they do not emit air pollution gases, do not 
consume oxygen, and do not generate nuisance noise). In addition they have a wide range of speed control, high torque and small size, high energy efficiency and their low operating costs leads to significant savings during operation. The disadvantage of electric drive systems is the relatively high cost of purchasing their individual components (inverter, battery pack) [14,15].

\section{Model of a Hybrid Barge Powertrain}

\subsection{Mathematical Description}

The barge drive models shown in Figures 3-5 have been developed in the MODELICA programming environment. These powertrain models were made using elements available in the Modelica Energy Storages library and Modelica Standard Library. The mathematical model was developed for a barge with a displacement of 2680 tons and following geometric dimensions: $110 \mathrm{~m}$ length, $11 \mathrm{~m}$ width, and $2.5 \mathrm{~m}$ draft. The barge geometry visualized in FREE!ship (The GNU General Public License (GPL), Boston, MA 02110, USA) [16] is shown in Figure 6.

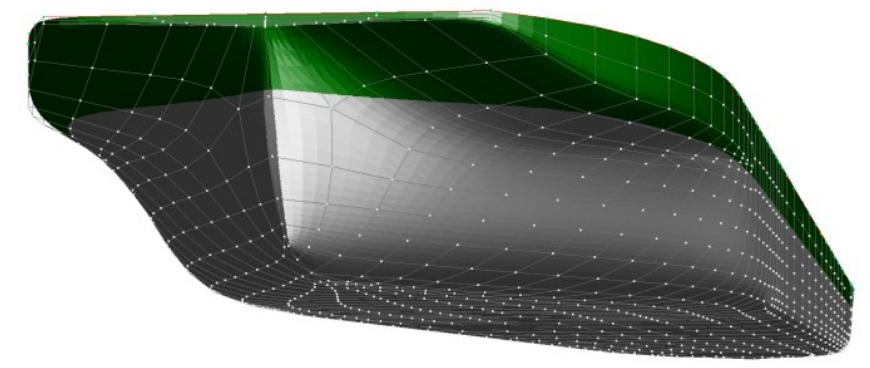

Figure 6. Geometric shape of the barge hull in FREE!ship [16].

For the given geometric shapes and the corresponding barge hull dimensions, the towing power demand at a specified speed is determined by the formula:

$$
P_{T}=R \cdot V
$$

where: $P_{T}$ —towing power $(\mathrm{W}) ; R$ —barge resistance $(\mathrm{N}) ; V$-barge velocity $(\mathrm{m} / \mathrm{s})$.

There are numerous methods of predicting the resistance of hull with its appendages and the surface parts of the ship [17-19]. One of these approaches is the improved Holtrop method [20], in which the hull resistance is calculated on a basis of experimental resistance data statistical analysis. The sum of several regression formulae is used to calculate the resistance occurring during the cruise of the ship:

$$
R_{T O T}=R_{F R}(1+k)+R_{A P}+R_{W V}+R_{B P}+R_{T P}+R_{R E S}+R_{A D},
$$

where: $R_{T O T}$-total resistance; $R_{F R}$-frictional resistance, calculated according to the ITTC-1957 procedure [21]; $(1+k)$-low speed hull form factor, represents how the hull shape affects the frictional resistance; $R_{A P}$-appendage resistance, shows the influence of various hull appendages such as rudders, keel, etc.; $R_{W V}$-wave resistance; $R_{B P}$-bulbous bow pressure resistance, effect caused by presence and shape of a bulbous bow; $R_{T P}$-transom pressure resistance, caused by immersed part of ship's transom; $R_{R E S}$-residual resistance, including hull surface roughness influence; $R_{A D}$-aerodynamic drag, caused by surface part of the ship.

The $(1+k)$ low speed hull form factor describes the influence of the hull shape on the frictional resistance component at low to moderate vessel speed. The Holtrop method uses the low speed form 
factor to calculate the speed dependent form factor, which approaches 1 at high vessel speeds. The low speed hull form factor is a regression formula dependent on several components:

$$
\begin{gathered}
(1+k)=0.93+0.487118 \cdot\left(1+0.011 \cdot C_{S}\right) \cdot\left(\frac{B}{L_{W}}\right)^{1.06806} \cdot\left(\frac{H}{L_{W}}\right) 0.46106 \cdot\left(\frac{L_{W}}{X}\right)^{0.121563} . \\
\cdot\left(\frac{L_{W}{ }^{3}}{D_{V}}\right) 0.36486 \cdot\left(1-P_{C}+Y\right)^{(-0.604247)} \\
X=L_{W}\left(1-P_{C}+\frac{0.06 \cdot P_{C} \cdot P C B}{4 \cdot P_{C}-1}\right) \\
Y=\left\{\begin{array}{l}
0 \text { if } P_{C} \leq 0.9 \\
0.4 \cdot\left(P_{C}-0.9\right) \text { if } P_{C}>0.9
\end{array}\right.
\end{gathered}
$$

where: $C_{S}$-stern shape coefficient; $B$-beam $(\mathrm{m}) ; L_{W}$-waterline length $(\mathrm{m}) ; H$-draft $(\mathrm{m})$; $D_{V}$-displaced volume $\left(\mathrm{m}^{3}\right) ; P_{C}$ - prismatic coefficient, the ratio of displaced volume to the volume of bounding box of submerged hull; $X$-length of run; $Y-P_{C}$ corrective coefficient; $P C B$-position of the center of buoyancy with respect to the center of the ship (halfway between perpendiculars), as a fraction of waterline length.

The appendage resistance component characterizes the effect of flow oriented hull appendages such as keels, skegs, rudders, stabilizer fins, and exposed propeller shafts:

$$
R_{A P}=0.5 \cdot \rho_{W} \cdot V^{2} \cdot \frac{\sum\left[\left(1+A_{C}\right) \cdot S_{A}\right]}{\sum S_{A}} \cdot C_{F} \cdot \sum S_{A},
$$

where: $\rho_{W}$-density of water $\left(\mathrm{kg} / \mathrm{m}^{3}\right) ; V$ - ship speed $(\mathrm{m} / \mathrm{s}) ; C_{F}$-frictional resistance coefficient, as in [21]; $A_{C}$-Appendage shape coefficient; $S_{A}$ - surface of appendage.

Aerodynamic drag $R_{A D}$ assumes still air with moving ship and shows the resistance caused by the apparent wind. This element of resistance equation is mostly concerning ships with large transverse surfaces, especially these capable of high speed e.g., warships. It is defined by the well-known drag equation:

$$
R_{A D}=0.5 \cdot \rho_{A} \cdot V_{A}^{2} \cdot A_{T} \cdot C_{T}
$$

where: $\rho_{A}$-density of air, typically $1.23\left(\mathrm{~kg} / \mathrm{m}^{3}\right) ; V_{A}$-ship velocity with respect to the surrounding air $(\mathrm{m} / \mathrm{s}) ; A_{T}$-transverse area of surface part of ship hull $\left(\mathrm{m}^{2}\right) ; C_{T}$-ship hull drag coefficient.

Knowing the value of towing power and resistance, it is possible to calculate the required power output of the motor (electric motor/internal combustion engine) used to drive the vessel. To determine the power of the propulsion engine, it is necessary to know the drive train efficiency, which consists of: hull efficiency $(0.95-1.05)$, the shaft line efficiency $(0.9-0.99)$, rotational efficiency $(1-1.07)$ and free running propeller efficiency (0.35-0.75):

$$
P_{M}=\frac{P_{T}}{\eta \cdot \eta_{H}}=\frac{P_{T}}{\eta_{S} \cdot \eta_{R} \cdot \eta_{R P} \cdot \eta_{H}}
$$

where: $P_{M}$ - power drive motor $(\mathrm{kW}) ; P_{T}$-towing power $(\mathrm{kW}) ; \eta$-drive train efficiency; $\eta_{H}$-barge hull efficiency; $\eta_{S}$-shaft efficiency; $\eta_{R}$-rotational efficiency; $\eta_{R P}$-free running propeller efficiency.

\subsection{Simulation Models}

The powertrain models used have been modified with new functionalities with respect to the blocks and elements available in the Modelica libraries, including: nonlinearity of internal resistance characteristics of the $\mathrm{LiFePO}_{4}$ battery pack and development of a heat capacity model including heat exchange with the environment, taking into account self-heating effect and temperature conditioning system allowing external heating and/or cooling of the battery pack. The layout also includes and models the interference affecting the hull of the ship in the form of river current and wind, barge loading 
condition and water level under the hull, propulsion and internal combustion engines. For internal combustion engines it is possible to select the fuel type of either pure diesel or Diesel-LNG fuel. The mentioned modifications regarding the drive system model are new in the presented publication. Similarly, the scope of research is new, due to the possibility of answering the question: in what extent wills the use of different configurations of hybrid systems, affect the reduction of fuel consumption and reduce poisonous gases to the atmosphere?

The main task of internal combustion engines in the system is to generate mechanical power. From the point of view of modeling components as a black box, the engine was modeled as an object into which the fuel is fed and controlled mechanical power is output. The equations connecting input and output and describing the internal combustion engine relate mainly to the description of energy conversion:

$$
P_{F}=P_{C}+P_{H}+P_{I R}
$$

where: $P_{F(\text { Fuel })}$ - power contained within the fuel, $P_{C(\text { Crankshaft })}$-effective power on the engine power take off shaft, $P_{H(\text { Heat })}$ - heat losses, $P_{\text {IR(Internal Resistance) }}$ - losses related to engine internal friction.

The fuel consumption for various engine speeds and corresponding power is implemented in the form of a curve based on the internal combustion engine manufacturer's data [22].

Figure 7 shows a model of the dual fuel Diesel-LNG-Propeller (DP, DLP) powertrain modeled in Modelica. The propulsion system consists of two dual fuel diesel engines with a nominal power of $760 \mathrm{~kW}$. The engines are coupled by a reduction gearbox, which rotates the single propeller. This powertrain configuration causes the engines to work at a changing load, determined by the set speed, and varying resistance of the hull moving through the water, depending on the apparent water speed.

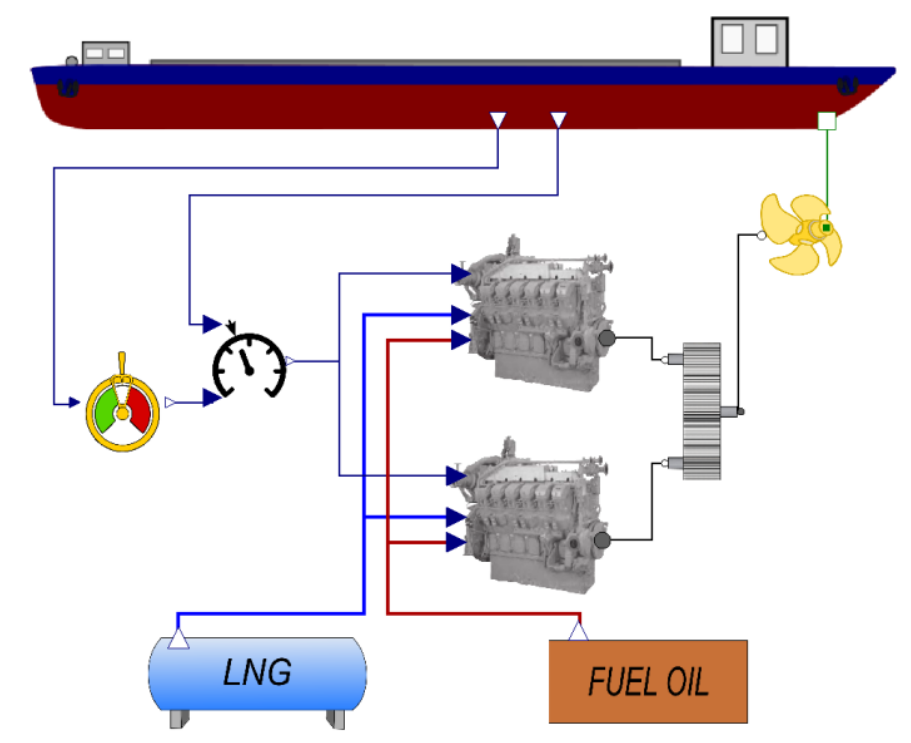

Figure 7. Model of a dual fuel LNG-Diesel (DP: Diesel-Propeller, DLP: Diesel-LNG-Propeller) powertrain developed in Modelica.

Figure 8 shows a model of a dual fuel LNG + Diesel-Electric-Propeller (DEP, DLEP) powertrain modeled in Modelica. This model expands the previous basic model, by addition of a third, smaller engine, with a nominal power of $250 \mathrm{~kW}$. All engines are now driving their generators which supply a common AC distribution bus. The main consumers on the bus are two power converters which drive their electric synchronous motors (530 kW nominal power each), coupled to a common reduction gearbox which drives the propeller. 


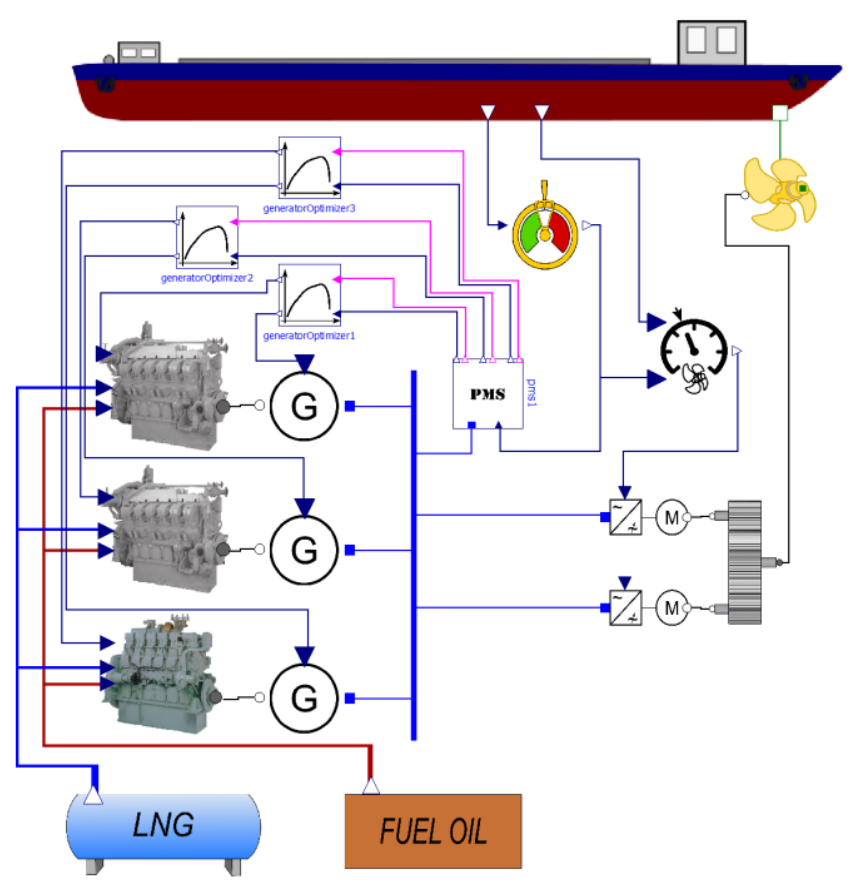

Figure 8. Model of a dual fuel LNG-Diesel-Electric (DEP, DLEP) powertrain developed in Modelica.

Figure 9 shows the model of the hybrid LNG + Diesel-Battery-Electric-Propeller (DBEP, DLBEP) powertrain modeled in Modelica.

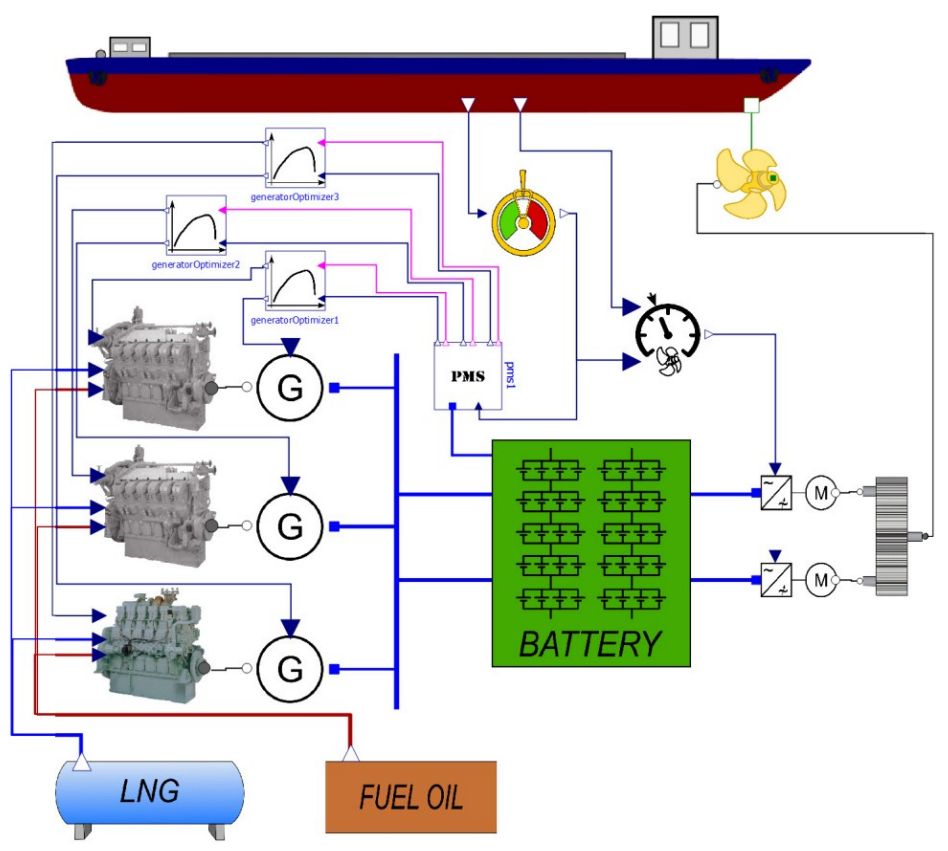

Figure 9. Model of a hybrid, dual fuel LNG-Diesel-Battery-Electric (DBEP: Diesel-BatteryElectric-Propeller, DLBEP: Diesel + LNG-Battery-Electric-Propeller) powertrain developed in Modelica.

It further expands the DEP model, by replacing the AC distribution network with a DC network, which is now powered by the generators via dedicated AC/DC power converters. The DC bus is coupled with battery energy storage having a capacity of $405 \mathrm{kWh}$ and a nominal voltage of $563 \mathrm{~V}$. The PMS system in this variant not only selects which engine generator sets are turned on, but it also 
controls the State of Charge (SOC) of the energy store. During periods of low power demand, the PMS can turn off all the diesel generators altogether, and allow the propulsion system to run on the energy stored in the batteries, until the battery state of charge drops to low charge limit 15\%. Upon reaching this limit, the Battery Management System (BMS) turns on the smallest diesel generator, and regulates its power output such that it operates in the optimal efficiency range. The generator provides power to the propulsion system, and the excess is used to recharge the batteries. In order not to stress the batteries by too large voltage occurring when the battery is almost fully charged, the BMS stops the charging and turns off the generator upon the battery reaching $90 \%$ SOC.

In the developed models, according to the manufacturer's data, the diesel fuel to LNG consumption ratio was set to $20 \%$ diesel- $80 \%$ LNG in the case the LNG fuel is selected. The model allows calculation of amount of each fuel spent, the total cost of fuel, as well as calculation of the amount of $\mathrm{CO}_{2}$ emitted during combustion of each fuel. The calculated weights of each consumed fuel are multiplied by the price of each fuel giving the total cost of journey. Components used for construction of the electric propulsion system including inverters [23-27], power converters [28-31], electric motors [15,32] and barge course control algorithms [33-39] can be implemented based on available methods and technologies $[13,40]$.

\section{Simulation Results}

Figure 10 shows profile of a route for a barge with a displacement of 2680 tons. A model of the route consisting of a $539 \mathrm{~km}$ stretch of a river running back and forth for a total of $1078 \mathrm{~km}$ was developed for the testing of propulsion systems. The mean barge speed of $18.52 \mathrm{~km} / \mathrm{h}(10 \mathrm{kn})$ was specified. The simulated barge starts its journey upstream the river, moving against the river current. After travelling $539 \mathrm{~km}$, at about $30 \mathrm{~h}$ mark, the barge reverses its course and flows downstream, with the river current, which reduces the necessary propulsive power.

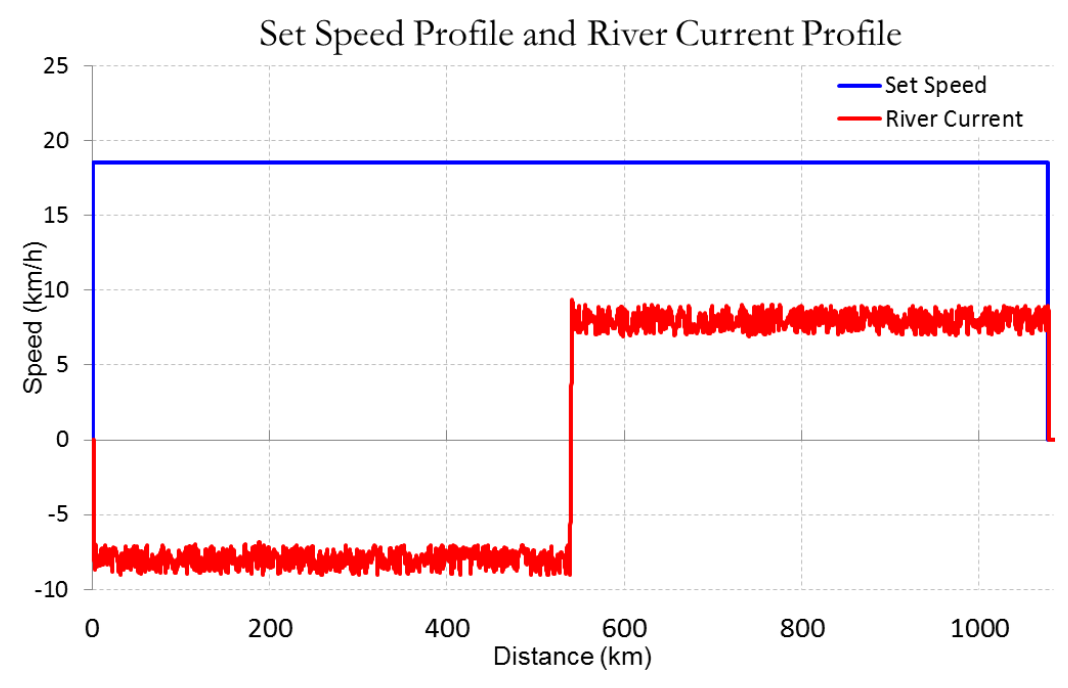

Figure 10. Barge speed profile set for the test route.

Figure 11 shows the results of energy consumption associated with the motion of the barge on a given test route for Diesel-Propeller (DP); Diesel + LNG-Propeller (DLP); Diesel-Electic-Propeller (DEP); Diesel + LNG-Electric-Propeller (DLEP), Diesel-Battery-Electric-Propeller (DBEP), and DLBEP. It was assumed that the dual fuel engine uses the same amount of energy from either fuel (diesel only, or LNG with $20 \%$ pilot diesel) to provide the same power, which caused the curves from each type of powertrain structure to become overlaid. There can be seen however, that the DP (DLP) structure requires the most energy, followed by DEP (DLEP), and the hybrid DBEP (DLBEP) requires the least energy. In the case of low propulsive power load, the action of battery energy storage can be seen, 
which causes cyclic operation between powering the propulsion solely from the battery, and operating only one diesel generator running at nearly full capacity to power the propulsion while recharging the battery.

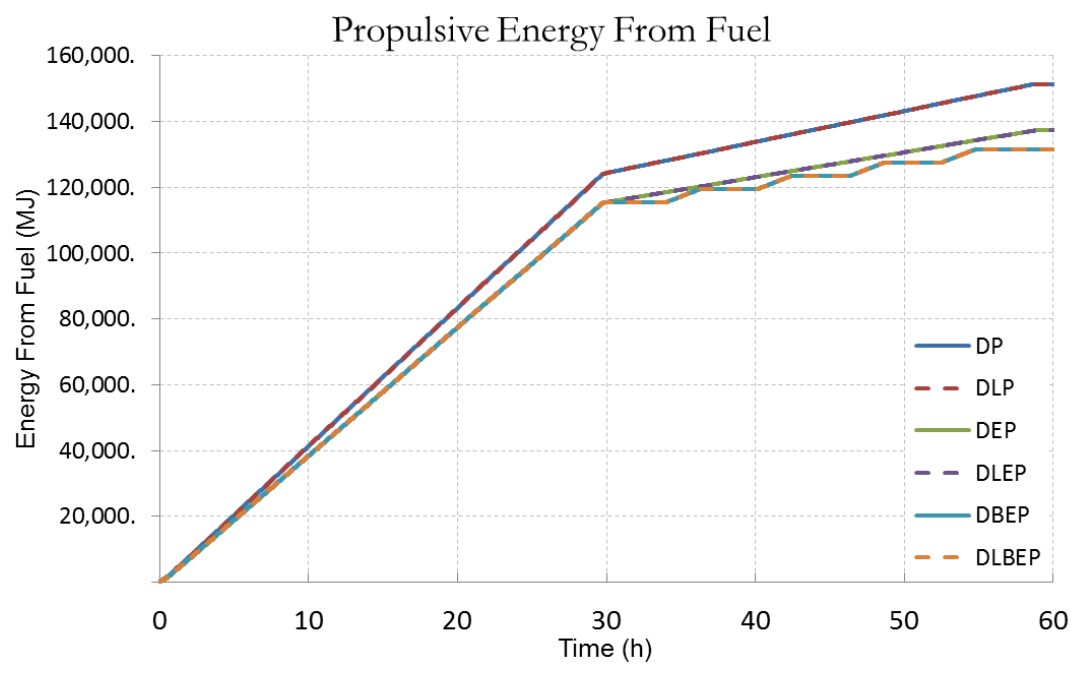

Figure 11. Plot of energy consumed from fuel for various powertrain configurations on the same test route. DP: Diesel-Propeller; DLP: Diesel + LNG-Propeller; DEP: Diesel-Electric-Propeller; DLEP: Diesel + LNG-Electric-Propeller; DBEP: Diesel-Battery-Electric-Propeller.

Figure 12 shows the $\mathrm{CO}_{2}$ emissions associated with the motion of the barge on a given test route depending on the powertrain tested. The reduced $\mathrm{CO}_{2}$ emissions from the LNG fueled variants can be seen.

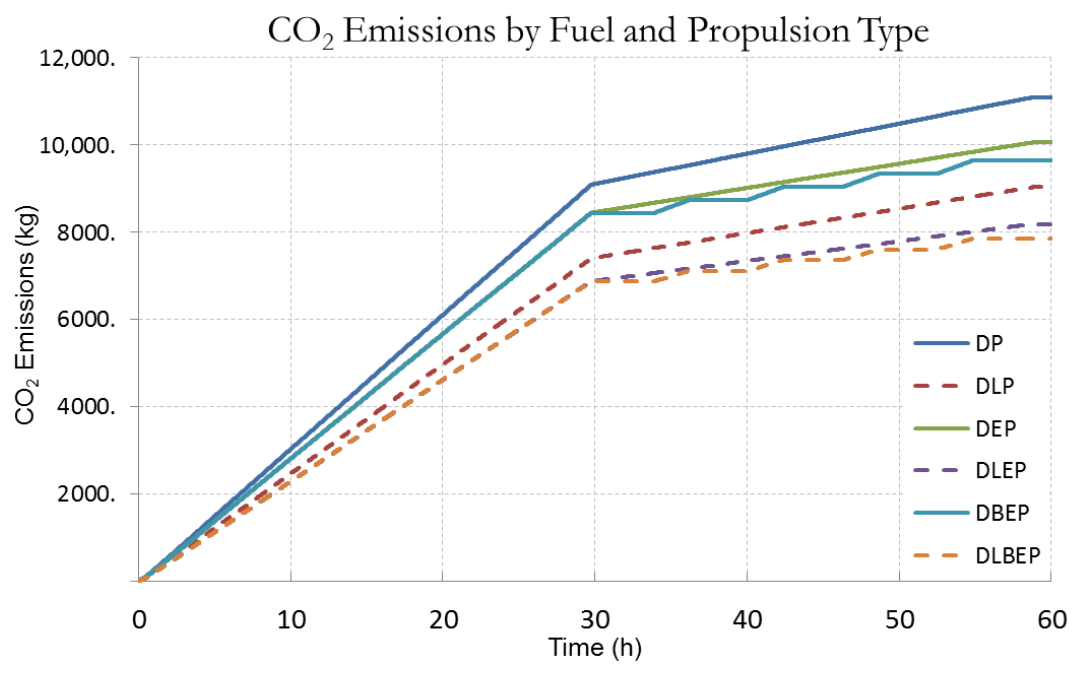

Figure 12. Plot of $\mathrm{CO}_{2}$ emissions by fuel type for various powertrain configurations on the same test route.

Figure 13 shows the fuel costs associated with the motion of the barge on a given test route depending on the powertrain tested. The simulation assumes the price of diesel (MGO-Marine Grade Oil) at $585 \mathrm{USD} /$ ton and the price of LNG at $261 \mathrm{USD} /$ ton. It also observes the consumption of $20 \%$ of energy in the form of diesel pilot fuel, used to initiate the combustion process in the dual fuel engine when using LNG fuel. 


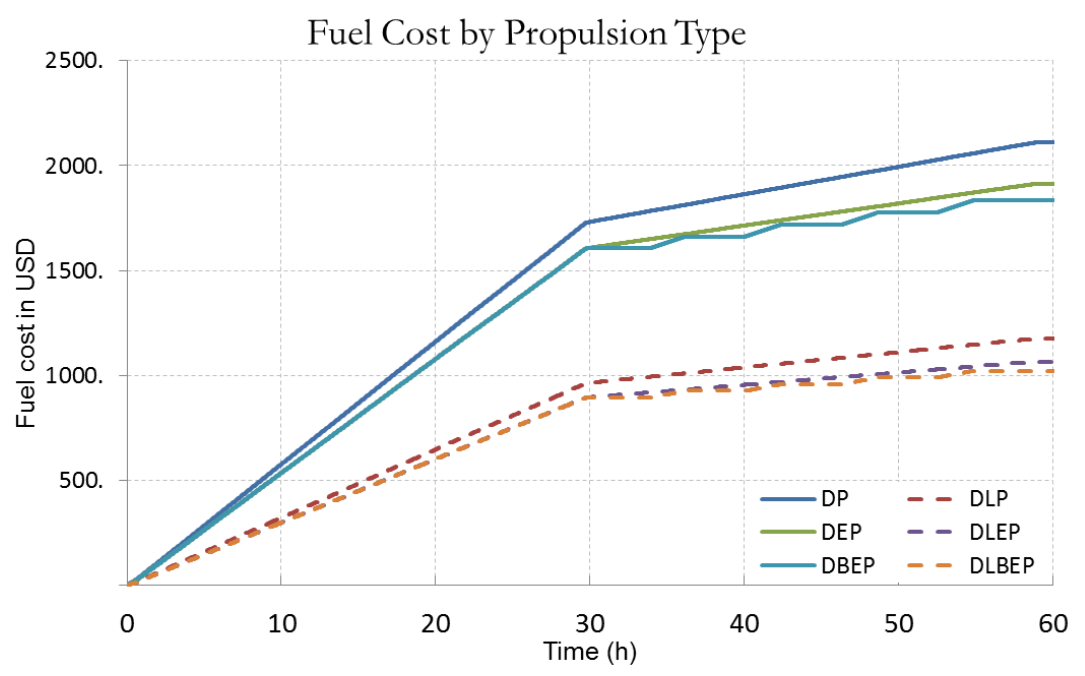

Figure 13. Plot of fuel cost by fuel type for various powertrain configurations on the same test route.

Figure 14 shows an example of the energy flow parameters of the DLBEP hybrid drive system during the cruise on the test route. At the very beginning, a brief surge in power can be noticed, when the barge accelerates to the set speed, a moment later the barge exits the stationary waters of the harbor, and begins the travel the river upstream. River current causes the increase in apparent water speed of the barge, increasing the hydraulic resistance causing the required propulsive power to rise.

Upon reaching the $539 \mathrm{~km}$ point, the simulated barge begins the return journey downstream, which greatly reduces the apparent water speed and the resistance drops. It allows the propulsion system to turn off the diesel generators for extended periods, as the energy stored in the batteries is used to propel the ship. When the battery becomes depleted, it is recharged by a generator selected by the PMS, in a way that it will be most efficient generator considering the load present from the propulsion system, and the preset recharge current.

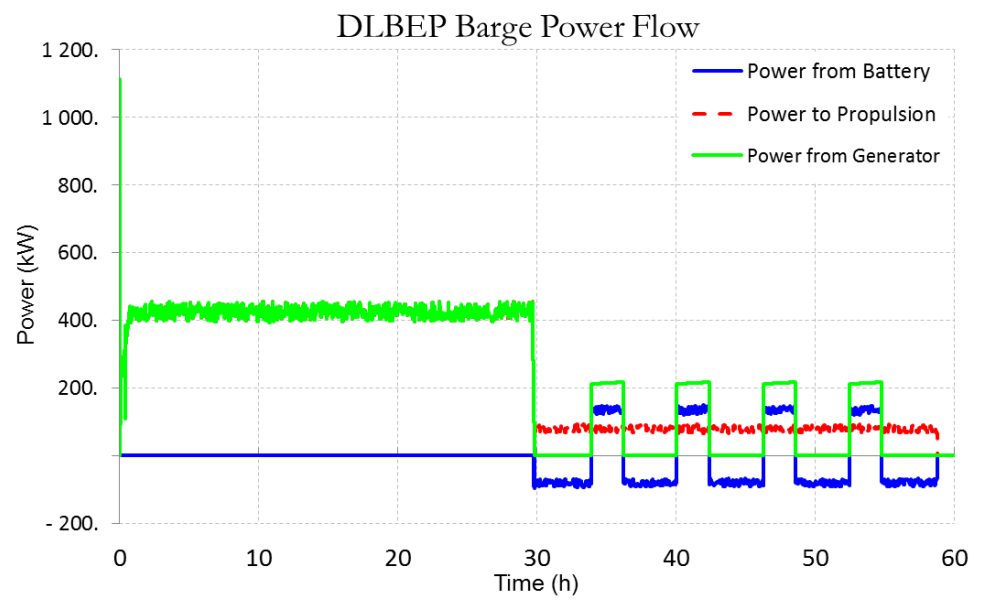

Figure 14. Plot of power flow between generators, battery and propulsion system, on a BLDEP variant barge, with utilization of battery energy store in the second part of journey.

Figure 15 illustrates some of the parameters associated with the barge propeller speed that translates into the inland barge speed over ground on the test route for the DLBEP. The journey consists of two runs (upstream and downstream the river), each about $30 \mathrm{~h}$ long at the set speed of $10 \mathrm{kn}$. Upon reaching the destination the modeled barge cuts off its propulsion which stops fuel and energy consumption. 


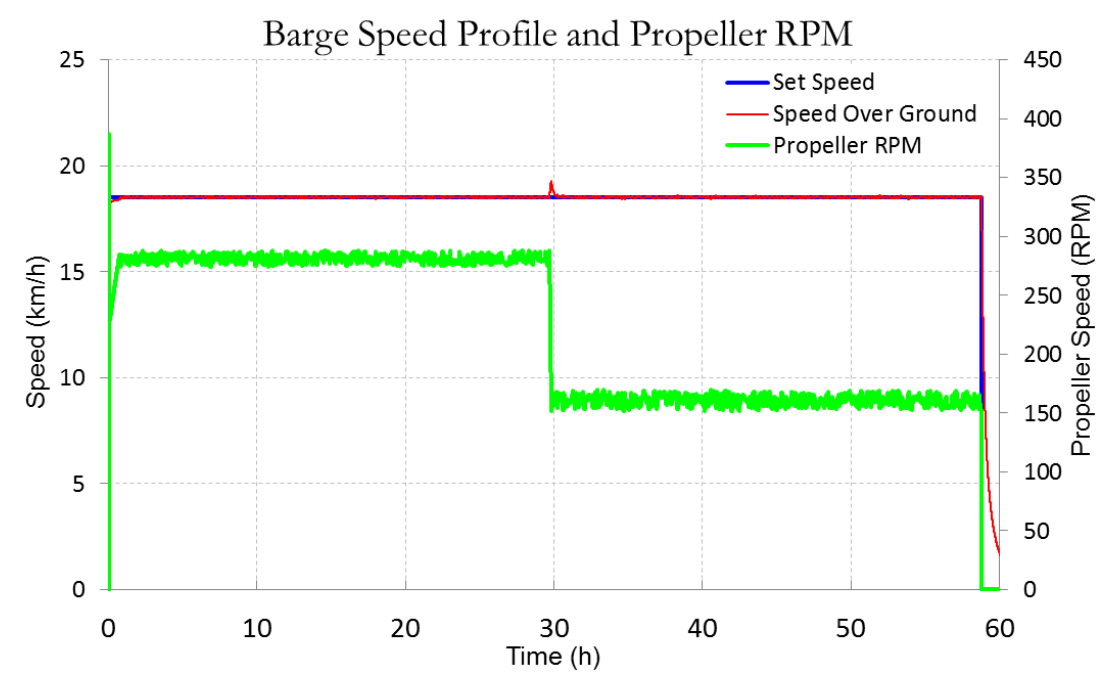

Figure 15. Plot of barge speed over ground, set speed and propeller RPM. The simulated journey is finished and propulsion is cut off at about $58 \mathrm{~h}$ mark.

\section{Discussion}

Based on the studies conducted, a lower energy consumption can be seen (Figure 11) with respect to DP drive in DBEP and DLBEP drives (-13.1\%), along with DEP and DLEP drives (-9.3\%). At the same time, the emission of $\mathrm{CO}_{2}$ into the atmosphere (Figure 12) decreased relative to the DP drive, respectively: DLBEP by $29.2 \%$; DLEP by $26.2 \%$; DLP by $18.6 \%$; DBEP by $13.1 \%$; DEP by $9.3 \%$.

An interesting phenomenon is the reduction of energy consumption by systems using electric motors (DEP, DLEP, DBEP, DLBEP) compared to diesel engine combustion systems (DP, DLP). This phenomenon shows us how optimal internal combustion engine loads (operating within $80-90 \%$ of rated power) affects energy savings.

Another positive effect of the hybrid drive system is the reduction in operating costs of the barge, expressed in USD (Figure 13). For the tested route in relation to the DP drive, the operating cost decreased for respectively: DLBEP by $51.6 \%$, DLEP by $49.5 \%$, DLP by $44.3 \%$, DBEP by $13.1 \%$ and DEP by $9.3 \%$.

Based on the results obtained, it can be stated that the use of the DLBEP barge drive system brings the greatest economic benefit to the ship owner and the environment. Comparison of the results obtained for DP and DBEP propulsion systems has confirmed that the use of hybrid technology reduces fuel consumption by $13.1 \%$ while the reduction stated in [5] is about $20 \%$. The comparison of operating costs between DP and DLBEP variants show a reduction on the order of $50 \%$. Assuming the initial investment cost for buying an electric powertrain on the order of 250 thousand $€$, and its subsequent operation for 250 days a year, the investment in DLBEP variant will pay off within 3 years, an into DBEP variant in about 14 years and 6 months.

An important parameter during the study was the assumed barge and river current speed. Changing the barge operating speed by several kilometers per hour has led to significant changes in energy consumption.

The use of the battery pack reduces operating costs especially when the barge moves with the river current and the electricity demand is not high (Figure 14). Another case in which the hybrid, battery backed propulsion system can present its advantage is during port maneuvers, or during mooring at a quay, when there is little demand for propulsive power, or the power is requested in short bursts. A battery energy store can handle such demand and does not require a diesel generator to operate which reduces costs and environmental pollution, including noise pollution.

The ability to select the configuration of powertrain (the operation of power sources with different nominal power levels) increases both functionality and efficiency of the hybrid powertrain. Presence of 
such flexibility in the propulsion system makes the barge more reliable and safe, because a malfunction of even two out of three diesel generators only limits the long term available power, and short term full propulsive power capability is retained thanks to the energy stored in the batteries. The hybrid variant has the ability to better perform time-critical maneuvers, such as during a crash stop condition, when full power astern is required to stop the vessel as soon as possible. The battery can handle the instantaneous request for power until the diesel generators start, even when depleted thanks to the $15 \%$ SOC reserve.

The mooring time spent during cargo operations, or otherwise, presents another opportunity for decreasing the cost and pollution emission, because the hybrid barge could recharge its large energy store from shore electricity grid, or even from local renewable energy sources, as these are becoming more viable and their availability also increases. Possibly in the future, a network of shore recharge stations could allow a zero-emission inland waterway transport to become reality.

The hybrid powertrain barge has the ability to enter the zones of silence in which the operation of loud machinery, such as diesel engines, is limited or prohibited. The barge can traverse such areas using the energy from the batteries, allowing greater operating range than vessels with conventional powertrain. For situations in which the barge moves down the river, and the current reduces the apparent speed, the generators can be switched on sporadically limiting the pollution and fuel consumption.

Taking into account the large number of barges and areas on which the barges operate, the benefits of adoption of hybrid systems seem measurable, especially when taking into account the future plans of extending and upgrading the existing waterway network. Such plans can take advantage of newly developed technologies and include them, causing positive effects, such as those presented in the hybrid powertrain.

\section{Conclusions}

Research has shown that the use of hybrid drive systems with electric motors, and in particular the DLBEP system, has brought the greatest savings in barge operation when compared to conventional internal combustion based systems.

The barge employing a hybrid propulsion system benefits from:

- Protection of the environment by significant reduction of air pollution gases.

- Reduction in energy consumption required to drive the barge. In addition, the use of the battery packs allows to reduce air pollution to zero during maneuvering e.g., in locks, allows operation in silence zones, and other areas where gaseous emissions and engine noise are undesirable or prohibited. This quality can be an essential property, especially for the intermodal freight transport model.

- Increased maneuverability.

- Enhanced safety level and reliability, by providing alternative types of propulsion and different propulsion system configurations in the event of damage to any of the propulsion system components (redundancy).

In addition, the electric battery packs of barge drive systems can be assisted by alternate sources of electricity such as wind turbines, photovoltaic panels and water turbines. Also the ability to charge packets from the power grid during e.g., night time, loading/unloading procedure, or during locking is also an option for reducing the costs of operation.

Funding: This research received no external funding.

Conflicts of Interest: The author declares no conflict of interest. 


\section{References}

1. Hsu, Y.-C.; Chung, C.-C.; Lee, H.-S.; Sherman, H.D. Evaluating and Managing Tramp Shipping Lines Performances: A New Methodology Combining Balanced Scorecard and Network DEA. INFOR 2013, 51, 130-141. [CrossRef]

2. Wang, S.; Qu, X.; Wang, T.; Yi, W. Optimal Container Routing in Liner Shipping Networks Considering Repacking $20 \mathrm{ft}$ Containers into $40 \mathrm{ft}$ Containers. J. Adv. Transp. 2017, 2017, 1-9. [CrossRef]

3. Ministry of Development. Assumptions for Plans for Development of Inland Waterways in Poland for 2016-2020 with Perspective until 2030. Available online: http://ungc.org.pl/wp-content/uploads/2016/04/ 26042016_Prezentacja_Ministerstwo_Rozwoju.pdf (accessed on 20 May 2018).

4. Inland Waterways Freight Transport-Quarterly and Annual Data. EUROSTAT. Available online: www.ec. europa.eu/eurostat/statistics-explained (accessed on 10 May 2018).

5. Moirangthem, K. Alternative Fuels for Marine and Inland Waterways. Eur. Comm. JRC Tech. Rep. $2016,2016$. [CrossRef]

6. Bach, R. Reduzierung des Dieselverbrauchs und der CO2-Emission durch Diesel-Direkten Hybridantrieb. Available online: http://www.bonapart.de/fileadmin/user_upload/HybridantriebRolf-Bach-Erfahrungsbericht.pdf (accessed on 10 May 2018).

7. Centobelli, P.; Cerchione, R.; Esposito, E. Environmental Sustainability and Energy-Efficient Supply Chain Management: A Review of Research Trends and Proposed Guidelines. Energies 2018, 11, 275. [CrossRef]

8. Simonsen, M.; Walnum, H.; Gössling, S. Model for Estimation of Fuel Consumption of Cruise Ships. Energies 2018, 11, 1059. [CrossRef]

9. Talavera, E.; Díaz-Álvarez, A.; Jiménez, F.; Naranjo, J. Impact on Congestion and Fuel Consumption of a Cooperative Adaptive Cruise Control System with Lane-Level Position Estimation. Energies 2018, 11, 194. [CrossRef]

10. Tibaquirá, J.; Huertas, J.; Ospina, S.; Quirama, L.; Niño, J. The Effect of Using Ethanol-Gasoline Blends on the Mechanical, Energy and Environmental Performance of In-Use Vehicles. Energies 2018, 11, 221. [CrossRef]

11. Central Statistical Office. 1950-2015, Statistical Yearbook. Available online: https://stat.gov.pl/files/gfx/ portalinformacyjny / en / defaultaktualnosci/3328/4/10/1/statistical_yearbook_of_the_regions_poland_ 2015.pdf (accessed on 12 May 2018).

12. Kulczyk, J.; Winter, J. Inland Water Transport; Publishing House of Wroclaw University of Technology: Wroclaw, Poland, 2003.

13. Masnicki, R. Validation of the Measurement Characteristics in an Instrument for Power Quality Estimation-A Case Study. Energies 2017, 10, 536. [CrossRef]

14. Zhang, C.; Guo, Q.; Li, L.; Wang, M.; Wang, T. System Efficiency Improvement for Electric Vehicles Adopting a Permanent Magnet Synchronous Motor Direct Drive System. Energies 2017, 10, 2030. [CrossRef]

15. Liu, X.; Lin, Q.; Fu, W. Optimal Design of Permanent Magnet Arrangement in Synchronous Motors. Energies 2017, 10, 1700. [CrossRef]

16. FREE!ship Plus. Available online: https://sourceforge.net/projects/freeship/ (accessed on 15 March 2018).

17. Di Mascio, A.; Broglia, R.; Muscari, R. Prediction of hydrodynamic coefficients of ship hulls by high-order Godunov-type methods. J. Mar. Sci. Technol. 2009, 14, 19-29. [CrossRef]

18. Maki, A.; Arai, J.; Tsutsumoto, T.; Suzuki, K.; Miyauchi, Y. Fundamental research on resistance reduction of surface combatants due to stern flaps. J. Mar. Sci. Technol. 2016, 21, 344-358. [CrossRef]

19. Zhang, H.; Liu, Z.; Zhan, C.; Feng, B. A sensitivity analysis of a hull's local characteristic parameters on ship resistance performance. J. Mar. Sci. Technol. 2016, 21, 592-600. [CrossRef]

20. Holtrop, J. A Statistical Resistance Prediction Method with a Speed Dependent Form Factor. In Proceedings of the 17th Session BSHC, Varna, Bularia, 17-22 October 1988; pp. 31-37.

21. Resistance Uncertainty Analysis, Example for Resistance Test; ITTC Recommended Procedures, Ed.; 2002. Available online: http:/ /ittc.info/media/2021/75-02-02-02.pdf (accessed on 10 May 2018).

22. Mitsubishi Turbocharger and Engine Europe B.V. Available online: www.mtee.eu (accessed on 11 May 2018).

23. Abu-Rub, H.; Guzinski, J.; Krzeminski, Z.; Toliyat, H.A. Predictive Current Control of Voltage-Source Inverters. IEEE Trans. Ind. Electron. 2004, 51, 585-593. [CrossRef]

24. Guzinski, J.; Abu-Rub, H. Speed sensorless induction motor drive with motor choke and predictive control. COMPEL Int. J. Comput. Math. Electr. Electron. Eng. 2011, 30, 686-705. [CrossRef] 
25. Guzinski, J.; Haitham, A.-R. Speed sensorless control of induction motors with inverter output filter. IREE Int. Rev. Electron. Eng. 2008, 3, 337-343.

26. Guo, Y.; Zheng, H.-Y.; Tan, X.-Y. Sensorless and Fuzzy Neuro-Network Control of IPMSM Drives for Ship Electric Propulsion. IEEE Mach. Learn. Cybern. 2007, 694-699. [CrossRef]

27. Husev, O.; Strzelecki, R.; Blaabjerg, F.; Chopyk, V.; Vinnikov, D. Novel Family of Single-Phase Modified Impedance-Source Buck-Boost Multilevel Inverters with Reduced Switch Count. IEEE Trans. Power Electron. 2016, 31, 7580-7591. [CrossRef]

28. Pawlak, M.; Radomski, G.; Kaplon, A. Experimental Verification of DC/DC Boost Converter Calculation Model Considering Conduction Losses; IEEE: Piscataway, NJ, USA, 2015.

29. Kaplon, A.; Rolek, J. Analysis of multipulse rectifiers with modulation in DC circuit in vector space approach. In Proceedings of the 2008 13th International Power Electronics and Motion Control Conference, Poznan, Poland, 1-3 September 2008; pp. 377-382. [CrossRef]

30. Stawczyk, P.; Karys, S. Three-Phase One-Branch Controlled Bridge Rectifier for Permanent Magnet AC Synchronous Generator. In Proceedings of the 2016 10th International Conference on Compatibility, Power Electronics and Power Engineering, Bydgoszcz, Poland, 29 June-1 July 2016; IEEE: Piscataway, NJ, USA, 2016.

31. Wei, Y.; Qiao, M.; Zhang, X.; Wu, Z. Parallel control study of multiple inverters for ship electric propulsion. In Proceedings of the 2011 International Conference on Electrical Machines and Systems, Beijing, China, 20-23 August 2011; pp. 1-4. [CrossRef]

32. Mansouri, M.M.; Mohamed-Seghir, M.M.; Nounou, H.N.; Nounou, M.N.; Abu-Rub, H. Bayesian methods for time-varying state and parameter estimation in induction machines. Int. J. Adapt. Control Signal Process. 2015, 29, 905-924. [CrossRef]

33. Kula, K. Model-based controller for ship track-keeping using Neural Network. In Proceedings of the 2015 IEEE 2nd International Conference on Cybernetics (CYBCONF), Gdynia, Poland, 24-26 June 2015; pp. 178-183.

34. Mohamed-Seghir, M. Methods based on fuzzy sets to solve problems of Safe Ship control. In Methods Based on Fuzzy Sets to Solve Problems of Safe Ship Control: Novel Algorithms and Techniques in Telecommunications and Networking; Mohamed-Seghir, M., Ed.; Springer: Dordrecht, The Netherlands, 2010; pp. 373-377.

35. Mohamed-Seghir, M. Safe Ship's Control in a Fuzzy Environment Using a Genetic Algorithm. Solid State Phenom. 2011, 180, 70-75. [CrossRef]

36. Lisowski, J. The Optimal and Safe Ship Trajectories for Different Forms of Neural State Constraints. Solid State Phenom. 2011, 180, 64-69. [CrossRef]

37. Lisowski, J. Analysis of Methods of Determining the Safe Ship Trajectory. TransNav 2016, 10, $223-228$. [CrossRef]

38. Gierusz, W.; Tomera, M. Logic thrust allocation applied to multivariable control of the training ship. Control Eng. Pract. 2006, 14, 511-524. [CrossRef]

39. Pomirski, J.; Rak, A.; Gierusz, W. Control system for trials on material ship model. Pol. Marit. Res. 2012, 19, 25-30. [CrossRef]

40. Strzelecki, R.; Mysiak, P.; Sak, T. Solutions of inverter systems in Shore-to-Ship Power supply systems. In Proceedings of the 2015 9th International Conference on Compatibility and Power Electronics (CPE), Costa da Caparica, Portugal, 24-26 June 2015; pp. 454-461.

(C) 2018 by the author. Licensee MDPI, Basel, Switzerland. This article is an open access article distributed under the terms and conditions of the Creative Commons Attribution (CC BY) license (http://creativecommons.org/licenses/by/4.0/). 